\title{
Perubahan Tingkat Kenyamanan berdasarkan Indeks Panas (Humidex) di Kalimantan Barat
}

\section{THE IMPACT OF CLIMATE CHANGE ON COMFORT LEVELS (HUMIDEX) IN WEST KALIMANTAN}

\author{
Fanni Aditya ${ }^{1^{*}}$, Jauharotul Khasanah ${ }^{2}$ \\ 1,2Stasiun Klimatologi Mempawah \\ *Email: faud77@gmail.com
}

Naskah masuk: 14 Oktober 2020 Naskah diperbaiki: 10 Maret 2021 Naskah diterima: 22 Maret 2021

\begin{abstract}
ABSTRAK
Tingkat kenyamanan merupakan interaksi antara manusia dengan lingkungan yang berkaitan dengan cuaca dan iklim. Hal ini cukup mempengaruhi kegiatan manusia baik di dalam maupun di luar ruangan. Kenaikan suhu yang diakibatkan oleh perubahan iklim berpotensi menyebabkan perubahan tingkat kenyamanan yang dirasakan oleh manusia. Hubungan antara unsur cuaca terhadap kenyamanan dapat diidentifikasi dengan Humidex. Penelitian ini dilakukan untuk mengkaji dampak perubahan iklim terhadap tren suhu udara dan tingkat kenyamanan termis pada periode $1990-2019$ pada 6 lokasi stasiun BMKG di wilayah Kalimantan Barat. Analisis perubahan suhu udara dilakukan dengan uji One-way ANOVA dan Uji Tukey. Selanjutnya Nilai indeks kenyamanan dihitung menggunakan Humidex. Hasil analisis menunjukkan suhu di Kalimantan Barat mengalami peningkatan selama periode 19902019. Humidex di wilayah Kalimantan Barat menunjukkan rata-rata humidex bulanan berkisar antara $37.5^{\circ} \mathrm{C}$ hingga $39.2^{\circ} \mathrm{C}$. Nilai ini menunjukkan bahwa kondisi tidak nyaman akibat panas sangat umum dirasakan di Kalimantan Barat. Humidex mengalami tren peningkatan pada periode 1990-2019. Tren humidex menunjukkan peningkatan pada frekuensi bulan dengan kategori $40-45^{\circ} \mathrm{C}$. Tren peningkatan suhu dan humidex menunjukkan bahwa telah terjadi perubahan iklim di Kalimantan Barat.
\end{abstract}

Kata kunci: Humidex, indeks kenyamanan, kenyamanan termis, perubahan iklim.

\begin{abstract}
The level of comfort is the interaction between human and environment related to weather and climate. This is sufficient to influence human activities both indoors and outdoors. Rising temperature caused by global warming potentially causes changes in the level of comfort. The relationship between the elements of weather and comfort can be identified with Humidex. The impact of climate change on trends in air temperature and thermal comfort levels in the period 1990-2019 at 6 BMKG stations in West Kalimantan. Analysis of changes in air temperature was carried out using One-way ANOVA test and Tukey test. Furthermore, the comfort index value is calculated using Humidex. The results of the analysis show that the temperature in West Kalimantan has increased during the period 1990-2019. Humidex in the West Kalimantan region shows an average monthly humidex ranging from $37.5^{\circ} \mathrm{C}$ to $39.2^{\circ} \mathrm{C}$. This value indicates that uncomfortable conditions due to heat are very common in West Kalimantan. Humidex experienced an increasing trend in the period 1990-2019. Humidex trends show an increase in the frequency of months within $40-45^{\circ} \mathrm{C}$ category. The trend of increasing temperature and humidex indicates that there has been climate change in West Kalimantan.
\end{abstract}

Keywords: Humidex, comfort index, thermal comfort, climate change. 


\section{Pendahuluan}

Kegiatan masyarakat Kalimantan Barat sangat dipengaruhi oleh kondisi kualitas lingkungan hidupnya. Salah satu aspek yang mempengaruhi kegiatan masyarakat adalah kondisi udara lingkungan sekitar [1]. Interaksi antara masyarakat dengan lingkungan khususnya parameter cuaca dan iklim sering disebut sebagai tingkat kenyamanan [2]. Kenyamanan baik di dalam dan luar ruangan sangat dipengaruhi oleh suhu udara. Suhu di atas nilai ambang batas menyebabkan ketidaknyamanan dan sangat mempengaruhi kondisi fisiologis manusia. Data yang digunakan adalah data suhu dan kelembaban rata-rata bulanan selama 30 tahun di enam stasiun, yaitu Stasiun Klimatologi Mempawah, Stasiun Meteorologi Supadio, Stasiun Meteorologi Sambas, Stasiun Meteorologi Melawi, Stasiun Meteorologi Sintang, dan Stasiun Meteorologi Ketapang.

Beberapa standar internasional menentukan dampak suhu pada kenyamanan termal [3]. Dalam Standar Nasional Indonesia (SNI) 031733-2004 mengatur kondisi rumah berdasarkan empat jenis kenyamanan (ruang, visual, audio, dan termal) kondisi penghuninya [4]. Kenyamanan termal tercapai ketika sensasi termal netral, tidak dingin atau hangat [5]. Kenaikan suhu yang diakibatkan oleh pemanasan global menyebabkan perubahan tingkat kenyamanan yang dirasakan manusia [6]. Kondisi kenyamanan yang dirasakan manusia sangat bervariasi dan memiliki subjektifitas yang tinggi. Kondisi ini berkaitan dengan jenis kenyamanan fisiologis manusia terhadap lingkungan sekitarnya [7].

Suhu merupakan salah satu indikator kenyamanan yang dapat dirasakan pada saat beraktifitas baik di dalam maupun diluar ruangan. Indikator ini disertai dengan kondisi kelembaban udara dapat digunakan untuk mengukur tingkat kenyamanan manusia [8] terutama di wilayah pemukiman dan perkantoran [9]. Pada Wilayah Kalimantan Barat yang masuk dalam iklim tropis, kondisi suhu tubuh manusia secara umum akan selalu berada di atas suhu lingkungan sekitarnya. Untuk menjaga keseimbangan panas pada suhu $37{ }^{\circ} \mathrm{C}$ tubuh manusia akan melakukan metabolisme [10].

Hubungan faktor cuaca dan iklim terhadap kondisi kesehatan dan kenyamanan manusia diidentifikasi dengan indeks biometeorologi. Salah satu indeks tingkat kenyamanan yang bisa digunakan dalam menggambarkan pengaruh suhu dan kelembaban udara terhadap manusia adalah Humidex. Indeks ini pada mulanya digunakan oleh ahli meteorologi Kanada dengan menggabungkan efek panas dan kelembaban udara untuk menggambarkan seberapa panas suhu terasa bagi manusia [11].

Metode Humidex memiliki kelebihan pada prakteknya yang mudah digunakan serta dapat diasosiasikan langsung dengan suhu yang dirasakan oleh manusia [2][10][18]. Pada penelitian yang dilakukan oleh [2] dan [7] menggunakan metode Humidex yang memiliki basis kenyamanan fisiologis menunjukkan bahwa kondisi kenyamanan termis pada kedua lokasi secara umum masuk dalam kategori tidak nyaman yang dirasakan oleh $50 \%$ populasi hingga seluruh populasi. Penelitian humidex telah dilakukan oleh [12] untuk mengetahui tingkat ketidaknyamanan akibat adanya perubahan iklim. Menurut Rana et al. [13] Humidex merupakan ukuran yang baik untuk analisis untuk kajian kenyamanan di dalam ruangan dengan kelembapan tinggi. Wilayah Kalimantan Barat mengalami peningkatan pembangunan yang cukup signifikan [14]. Selain itu, lokasinya yang berada di wilayah khatulistiwa memperoleh radiasi matahari yang tinggi. Dari latar belakang tersebut maka tujuan penelitian ini adalah untuk mengetahui tren perubahan suhu dan perubahan tingkat kenyamanan termis akibat perubahan iklim dengan menggunakan humidex di wilayah Kalimantan Barat

\section{Metode Penelitian}

Data yang digunakan untuk dalam analisis perubahan suhu dan menghitung humidex dalam penelitian ini adalah data suhu dan kelembaban rata-rata bulanan selama 30 tahun di enam stasiun, yaitu Stasiun Klimatologi Mempawah, Stasiun Meteorologi Supadio, Stasiun Meteorologi Sambas, Stasiun Meteorologi Melawi, Stasiun Meteorologi Sintang, dan Stasiun Meteorologi Ketapang. Letak geografis dan posisi stasiun terdapat pada tabel 1 dan Gambar 1 berikut:

Tabel 1. Letak geografis stasiun penelitian.

\begin{tabular}{ccccc}
\hline No & Nama Stasiun & Lintang & Bujur & $\begin{array}{c}\text { Elevasi } \\
(\mathrm{M})\end{array}$ \\
\hline \hline & Stasiun & $00^{\circ} 09^{\prime}$ & $109^{\circ}$ & \\
1 & Meteorologi & $00.0^{\prime \prime}$ & $24^{\prime}$ & 3 \\
& Supadio & LS & $00.0^{\prime \prime}$ & \\
& & BT &
\end{tabular}




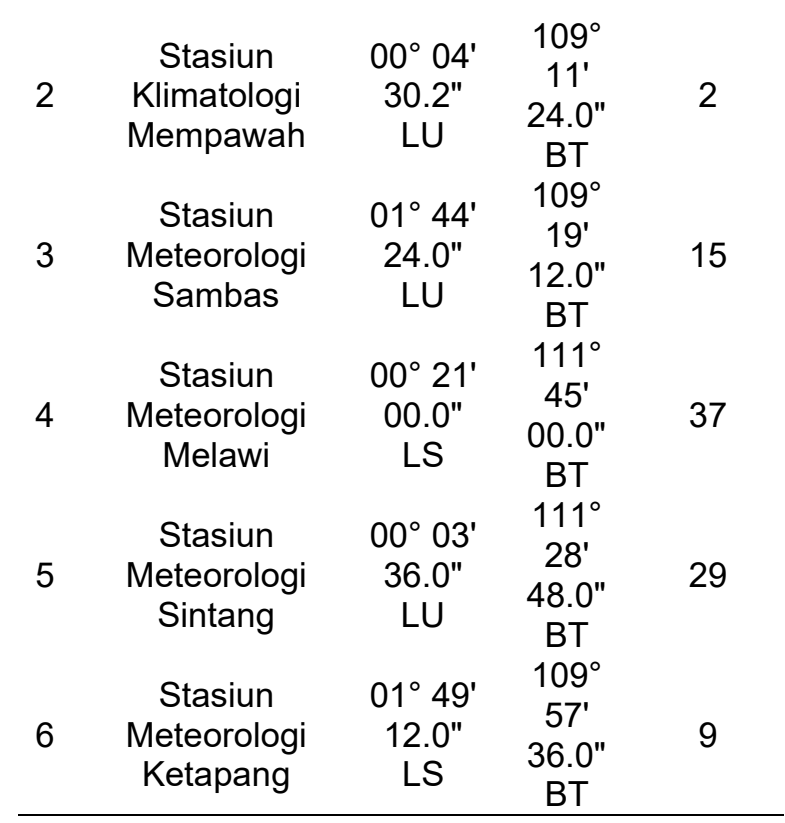

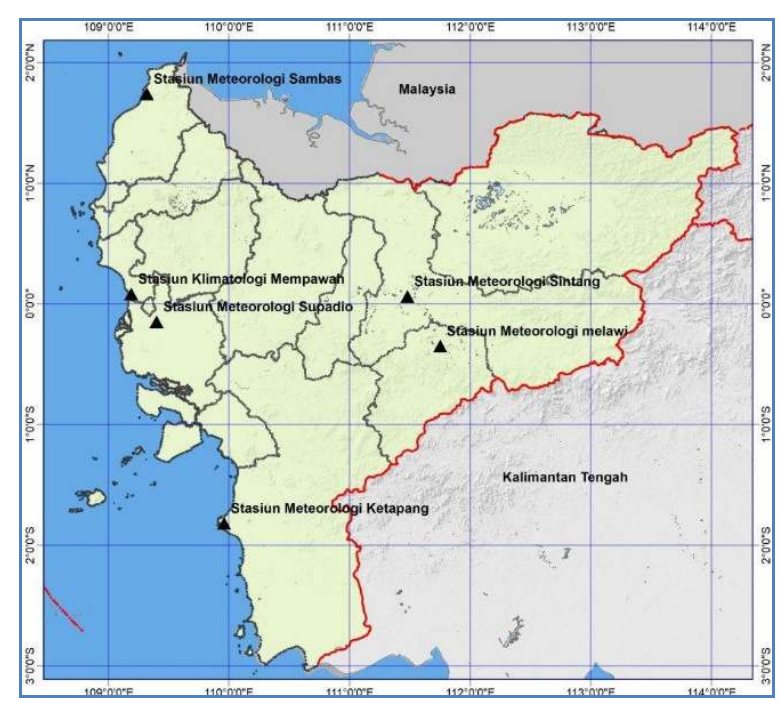

Gambar 1. Lokasi penelitian di Provinsi Kalimantan Barat.

Data suhu di lokasi penelitian dikelompokkan kedalam tiga periode waktu yaitu periode pertama (I) tahun 1990-1999, periode kedua (II) tahun 2000-2009, dan periode ketiga (III) 2010-2019. Kemudian dianalisis dengan statistik deskriptif dan uji sidik ragam searah (one-way ANOVA; $\alpha: 0,05$ ) dan dilanjutkan dengan uji Beda Nyata Jujur (Tukey HSD) dengan tingkat kepercayaan 95\% ( $\alpha=0.05)$ jika terdapat perbedaan yang signifikan dengan hipotesis sebagai berikut:

H0 : Tidak ada perbedaan rata-rata antar periode waktu.

$\mathrm{H} 1$ : Ada perbedaan rata-rata antar periode waktu.
Uji Tukey menunjukkan signifikansi dari perbedaan rata-rata yang diujicobakan. Nilai rata-rata yang memiliki huruf $(A, B, C)$ berbeda maka memiliki perbedaan yang signifikan, sebaliknya, nilai rata-rata yang memiliki huruf yang sama tidak memiliki perbedaan yang signifikan.

Humidex yang dikenal sebagai indeks panas merupakan ukuran dari ketidaknyamanan termal yang mampu mempengaruhi kenyamanan manusia [15]. Menurut [11], Humidex menghubungkan ketidaknyamanan termis di luar ruangan dengan menggunakan dua parameter utama meteorologi, yaitu suhu udara dan kelembapan relatif yang dirumuskan dengan persamaan sebagai berikut:

$$
\begin{aligned}
& \text { humidex }=\mathrm{T}+\frac{5}{9}(e-10) \\
& \mathrm{e}=6.112 \times 10^{\left(\frac{7 . \mathrm{T}}{\mathrm{gng} T \mathrm{~T}}\right)} \times \frac{\mathrm{RH}}{100}
\end{aligned}
$$

Dengan:

Humidex $=$ Indeks panas $\left({ }^{\circ} \mathrm{C}\right)$

$\mathrm{T} \quad=$ Suhu udara rata-rata $\left({ }^{\circ} \mathrm{C}\right)$

$\mathrm{RH}=$ Kelembaban relatif rata-rata (\%)

Nilai humidex dapat diinterpretasikan dengan sensasi panas berdasarkan klasifikasi dari [16] pada tabel 2. Sensasi panas yang diperoleh dari perhitungan Humidex adalah untuk luar ruangan (outdoor) karena data suhu dan kelembaban yang digunakan merupakan data hasil pengukuran di luar ruangan.

Tabel 2. Interpretasi Humidex dengan sensasi

\begin{tabular}{|c|c|}
\hline Kategori Interpretasi & $\begin{array}{c}\text { Indeks } \\
\text { Humidex }\end{array}$ \\
\hline Nyaman & $\leq 29^{\circ} \mathrm{C}$ \\
\hline Perasaan sedikit tidak nyaman & $30-34{ }^{\circ} \mathrm{C}$ \\
\hline Perasaan tidak nyaman & $35-39^{\circ} \mathrm{C}$ \\
\hline $\begin{array}{l}\text { Perasaan sangat tidak nyaman } \\
\text { akibat panas hingga } \\
\text { menimbulkan rasa tersengat } \\
\text { akibat panas }\end{array}$ & $40-45^{\circ} \mathrm{C}$ \\
\hline $\begin{array}{l}\text { Perasaan sangat tidak nyaman } \\
\text { dan hampir dapat } \\
\text { menyebabkan penyakit akibat } \\
\text { serangan panas }\end{array}$ & $46-53^{\circ} \mathrm{C}$ \\
\hline Kematian akibat panas & $\geq 54{ }^{\circ} \mathrm{C}$ \\
\hline
\end{tabular}
panas [16] 
Perhitungan frekuensi Humidex sepanjang periode 1990-2019 dilakukan berdasarkan kategori interpretasi Humidex sesuai dengan Tabel 2 dengan menggunakan metode histogram. Analisis trend dalam penelitian ini dilakukan terhadap nilai Humidex rata-rata tahunan dengan menggunakan tren. Analisis tren digunakan untuk melihat pergerakan data yang menunjukkan arah perkembangan menuju ke satu titik (cenderung naik/turun) untuk periode lebih dari sepuluh tahun.

\section{Hasil dan Pembahasan}

Berdasarkan analisis suhu rata-rata tahun 1990 - 2019 di Kalimantan Barat sebesar $26.8^{\circ} \mathrm{C}$ dengan nilai rata-rata tertinggi pada bulan Mei sebesar $27.4^{\circ} \mathrm{C}$, nilai rata-rata terendah pada bulan desember dan januari sebesar $26.4^{\circ} \mathrm{C}$. Kelembaban udara rata-rata tahun 1990 - 2019 sebesar $85.7 \%$ dengan nilai rata-rata tertinggi pada bulan desember sebesar $87.7 \%$ dan rata-rata terendah pada bulan agustus sebesar $83.2 \%$. Suhu Rata-rata yang tinggi pada bulan Mei karena posisi geografis lokasi penelitian di Kalimantan Barat yang sebagian besar berada di wilayah khatulistiwa. Akibat gerak semu tahunan matahari dan kemiringan sumbu bumi, bulan mei menjadi bulan dengan rata-rata suhu tertinggi selama 30 tahun. Sebaliknya, Kelembaban rata-rata tertinggi ada di bulan Desember, hal ini berasosiasi dengan curah hujan yang tinggi di bulan tersebut sehingga kelembaban juga menjadi tinggi.
Parameter cuaca lainnya seperti radiasi matahari juga berperan penting dalam mempengaruhi tingkat ketidaknyamanan termal (Humidex). Menurut [17] peningkatan radiasi matahari akan mengakibatkan peningkatan suhu udara dan penurunan kelembaban udara $(\mathrm{RH})$, begitupun sebaliknya. Berdasarkan pernyataan tersebut pengaruh radiasi matahari terhadap humidex dapat direpresentasikan oleh suhu udara. Sedangkan untuk parameter kecepatan angin, menurut [18] kecepatan angin tidak memiliki pengaruh signifikan terhadap nilai humidex.

Dari hasil analisis One-way ANOVA dan Uji Tukey selama tiga dekade (1990-2019) suhu di Kalimantan Barat mengalami peningkatan yang nyata dengan nilai $p$-value seluruhnya dibawah 95\% ( $\alpha=0.05$ ). Pada lokasi Kubu Raya dan Sambas uji Tukey menunjukkan walaupun ada perbedaan rata-rata yang nyata antara periode pertama dan kedua namun tidak signifikan sehingga masuk dalam kategori yang sama. Periode ketiga pada lokasi lainnya memiliki perbedaan rata-rata yang nyata dan signifikan yang ditunjukkan dengan huruf yang berbeda dengan periode sebelumnya. Pada lokasi Ketapang, Melawi, Mempawah dan Sintang Hasil uji Tukey menunjukkan ada perbedaan signifikan di ketiga periode waktu dan peningkatan suhu yang makin tinggi dari periode pertama hingga periode ketiga. Hasil ini sesuai dengan penelitian yang dilakukan oleh [19] yang menunjukkan adanya peningkatan suhu yang konsisten di daerah Mempawah pada periode 30 tahun.

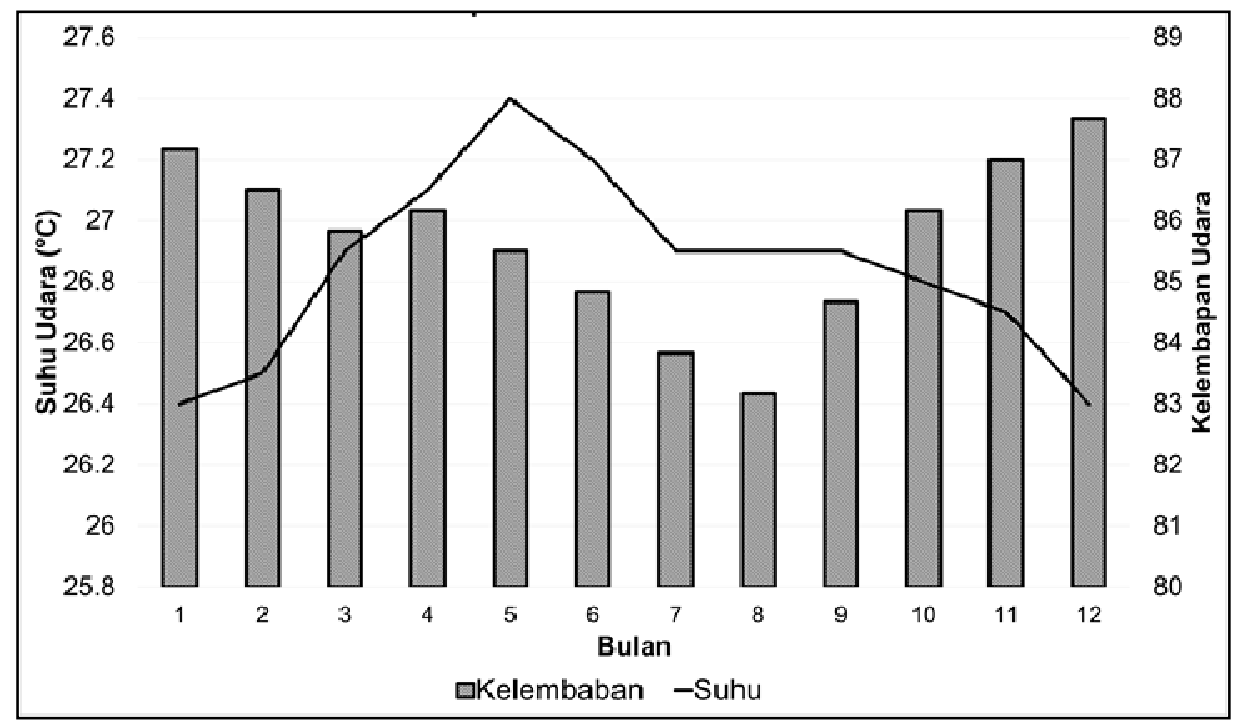

Gambar 2. Rata-rata suhu dan kelembaban di Kalimantan Barat periode 1990-2019. 
Tabel 3. Hasil One-way ANOVA dan Uji Tukey suhu udara rata-rata.

\begin{tabular}{|c|c|c|c|c|c|}
\hline \multirow[b]{2}{*}{ Lokasi } & \multirow[b]{2}{*}{ Ket } & \multicolumn{3}{|c|}{ Periode (Tahun) } & \multirow[b]{2}{*}{$\begin{array}{l}\text { P-Value } \\
\text { (Anova) }\end{array}$} \\
\hline & & $\begin{array}{c}1990- \\
1999\end{array}$ & $\begin{array}{l}2000- \\
2009\end{array}$ & $\begin{array}{l}2010- \\
2019\end{array}$ & \\
\hline \multirow{2}{*}{ Kubu Raya } & Rata-rata & 26,77 & 26,79 & 26,97 & \multirow{2}{*}{0.001} \\
\hline & Uji Tukey & B & B & A & \\
\hline \multirow{2}{*}{ Ketapang } & Rata-rata & 26,80 & 27,13 & 27,55 & \multirow{2}{*}{0.000} \\
\hline & Uji Tukey & C & B & A & \\
\hline \multirow{2}{*}{ Melawi } & Rata-rata & 26,54 & 26,72 & 26,99 & \multirow{2}{*}{0.000} \\
\hline & Uji Tukey & C & B & A & \\
\hline \multirow{2}{*}{ Mempawah } & Rata-rata & 26,57 & 26,83 & 27,20 & \multirow{2}{*}{0.000} \\
\hline & Uji Tukey & C & B & A & \\
\hline \multirow{2}{*}{ Sambas } & Rata-rata & 26,65 & 26,49 & 26,98 & \multirow{2}{*}{0.000} \\
\hline & Uji Tukey & B & B & A & \\
\hline \multirow{2}{*}{ Sintang } & Rata-rata & 26,68 & 26,88 & 27,04 & \multirow{2}{*}{0.000} \\
\hline & Uji Tukey & C & B & A & \\
\hline
\end{tabular}

Hasil perhitungan humidex pada gambar $3 \mathrm{di}$ wilayah Kalimantan Barat menunjukkan ratarata humidex bulanan berkisar antara $37.5^{\circ} \mathrm{C}$ hingga $39.2^{\circ} \mathrm{C}$. Berdasarkan tabel 2, nilai ini menunjukkan bahwa kondisi tidak nyaman akibat panas sangat umum dirasakan di Kalimantan Barat. Pola humidex cenderung mirip pola suhu bulanan dengan nilai tertinggi terjadi pada bulan Mei dan nilai terendah pada bulan Agustus. Lokasi Ketapang memiliki ratarata bulanan tertinggi sebesar $38,56^{\circ} \mathrm{C}$ dan Melawi memiliki rata-rata bulanan terendah sebesar $37,12^{\circ} \mathrm{C}$. Grafik nilai humidex menunjukkan adanya perbedaan antara wilayah yang relatif lebih dekat ekuator (Kubu Raya, Melawi, Mempawah, dan Sintang) dengan wilayah yang relatif lebih jauh dari ekuator (ketapang dan Sambas).

Humidex menunjukkan nilai suhu yang lebih tinggi dibandingkan suhu udara di lokasi penelitian. Hasil ini juga serupa dengan penelitian sebelumnya [2][20]. Penelitian oleh [21] menunjukkan adanya kaitan antara kelembaban tinggi yang terjadi menyebabkan terganggunya evaporasi dari tubuh manusia sehingga menyebabkan rasa tidak nyaman yang dirasakan oleh manusia. Rasa tidak nyaman ini dapat menyebabkan peningkatan stress bagi manusia [22]. Humidex merupakan gambaran tingkat panas yang dirasakan oleh manusia akibat kondisi suhu dan kelembaban tertentu.

Berdasarkan nilai humidex bulanan, tren Humidex di lokasi penelitian menunjukkan peningkatan pada periode 1990 - 2019. Tren peningkatan terbesar terjadi di Ketapang sebesar $0.09^{\circ} \mathrm{C}$. tren peningkatan di lokasi lain adalah $0.07^{\circ} \mathrm{C}$ di Melawi, $0.03^{\circ} \mathrm{C}$ di Kubu Raya, $0.08^{\circ} \mathrm{C}$ di Mempawah, $0.06^{\circ} \mathrm{C}$ di Sambas, dan $0.07^{\circ} \mathrm{C}$ di Sintang. Tren peningkatan selama 30 tahun tersebut tidak menunjukkan perubahan signifikan dari nilai humidex. Secara Klimatologis masyarakat di Kalimantan Barat merasakan kondisi panas tidak nyaman yang sama pada tahun 2019 maupun pada tahun 1990. Frekuensi kejadian sensasi panas bulanan di Kalimantan Barat berdasarkan nilai humidex tahun 1990-2019 menunjukkan $0.04 \%$ masuk dalam kategori "sedikit tidak nyaman", $82.47 \%$ masuk dalam kategori "tidak nyaman", dan $17.48 \%$ masuk dalam kategori "sangat tidak nyaman akibat panas hingga menimbulkan rasa tersengat akibat panas". 


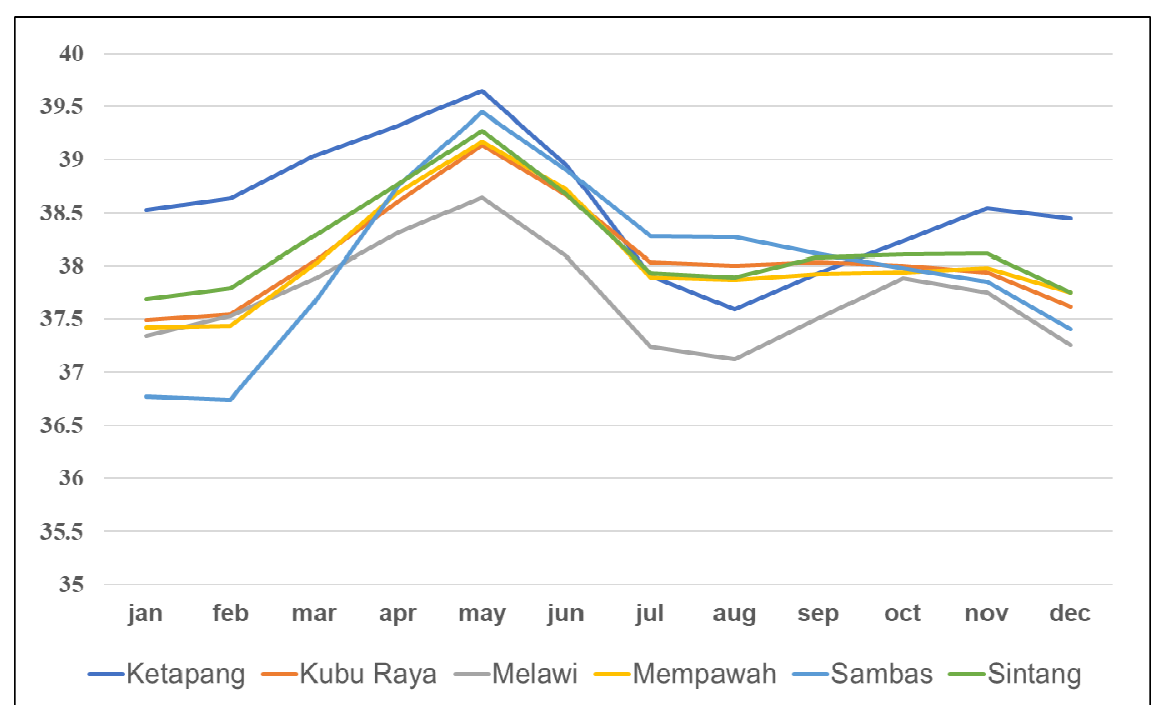

Gambar 3. Humidex rata-rata bulanan.

Tabel 4. Kategori humidex di lokasi penelitian.

\begin{tabular}{|c|c|c|c|c|c|c|}
\hline \multirow{2}{*}{ Lokasi } & \multicolumn{6}{|c|}{ Kategori Humidex (\%) } \\
\hline & $\leq 29^{\circ} \mathrm{C}$ & $30-34^{\circ} \mathrm{C}$ & $35-39^{\circ} \mathrm{C}$ & $40-45^{\circ} \mathrm{C}$ & $46-53^{\circ} \mathrm{C}$ & $\geq 54^{\circ} \mathrm{C}$ \\
\hline Ketapang & & & 68.89 & 31.11 & & \\
\hline Kubu Raya & & & 85.56 & 14.44 & & \\
\hline Melawi & & & 95.00 & 5.00 & & \\
\hline Mempawah & & & 83.89 & 16.11 & & \\
\hline Sambas & & & 81.76 & 18.33 & & \\
\hline Sintang & & 0.28 & 79.72 & 20.00 & & \\
\hline
\end{tabular}

Nilai interpretasi humidex bulanan pada rentang Perasaan sangat tidak nyaman akibat panas hingga menimbulkan rasa tersengat akibat panas di beberapa lokasi penelitian menunjukkan kecenderungan peningkatan pada tahun 2010-2019 dibandingkan periode tahun sebelumnya dan peningkatan terbesar terjadi di Ketapang, Sambas, dan Sintang. Nilai interpretasi pada rentang $40^{\circ} \mathrm{C}-45^{\circ} \mathrm{C}$ tersebut sering terjadi pada bulan Mei dengan persentase sebesar 54\% diikuti bulan April sebesar 14\% dan Maret sebesar $10 \%$.
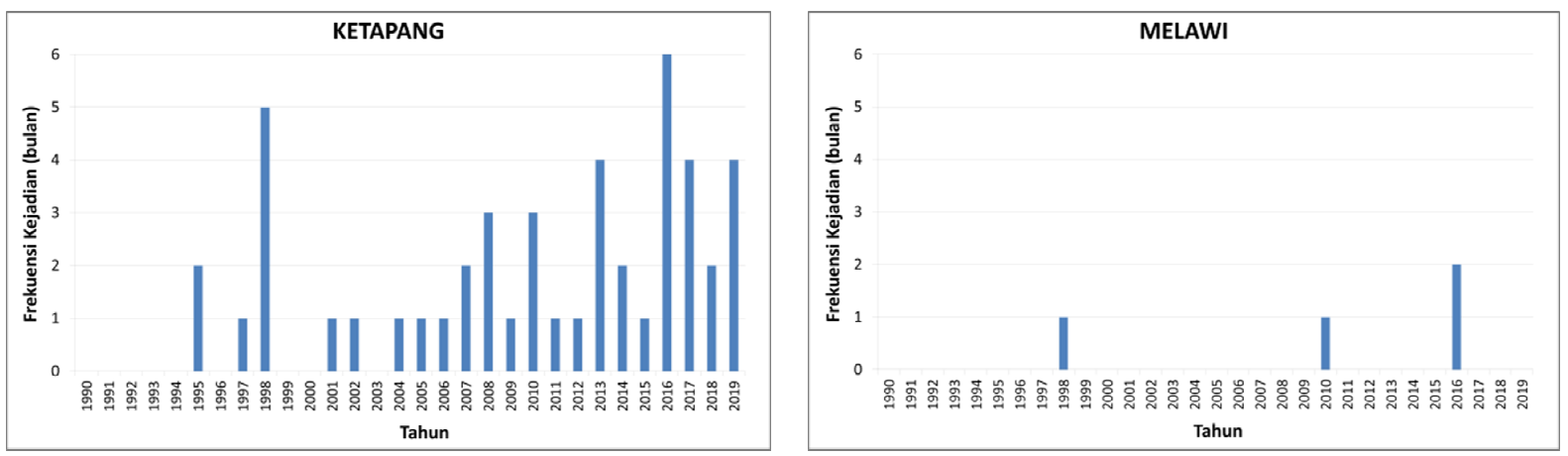

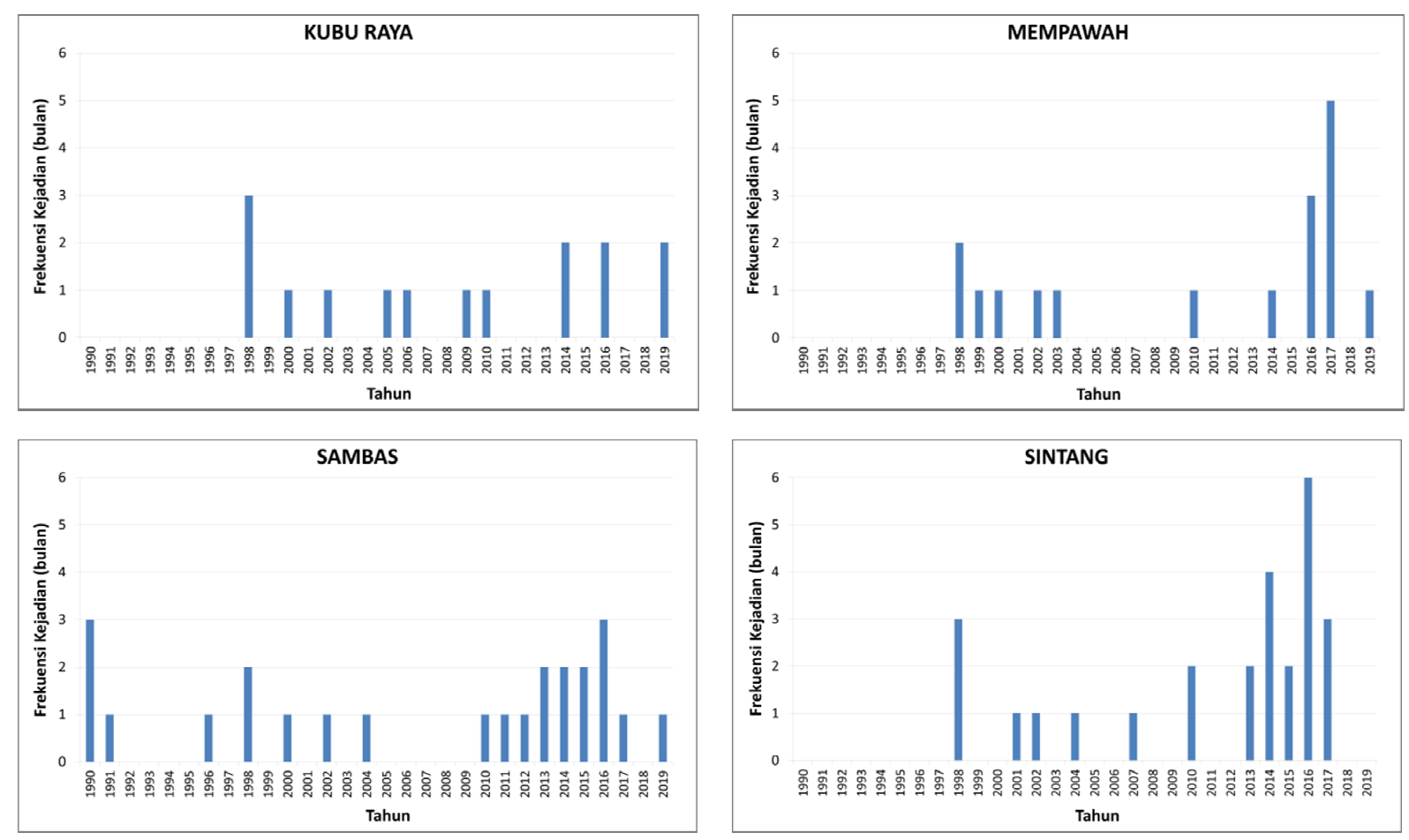

Gambar 4. Frekuensi humidex pada kategori $40-45^{\circ} \mathrm{C}$.

Humidex pada kategori $40-45^{\circ} \mathrm{C}$ yaitu perasaan sangat tidak nyaman akibat panas hingga menimbulkan rasa tersengat akibat panas merupakan kategori tertinggi yang terdapat di 6 lokasi pengamatan. Berdasarkan grafik di atas, pada kurun waktu 30 tahun (1990-2019) secara umum terdapat peningkatan frekuensi kejadian. Peningkatan kejadian yang cukup signifikan terjadi pada 10 tahun terakhir (2010-2019).
Kategori interpretasi sensasi panas tersebut dibuat di wilayah beriklim sub-tropis yang berbeda dengan iklim tropis, sehingga persepsi mengenai sensasi panas yang dirasakan manusia di lingkungan tropis berdasarkan Humidex membutuhkan penelitian lebih lanjut.

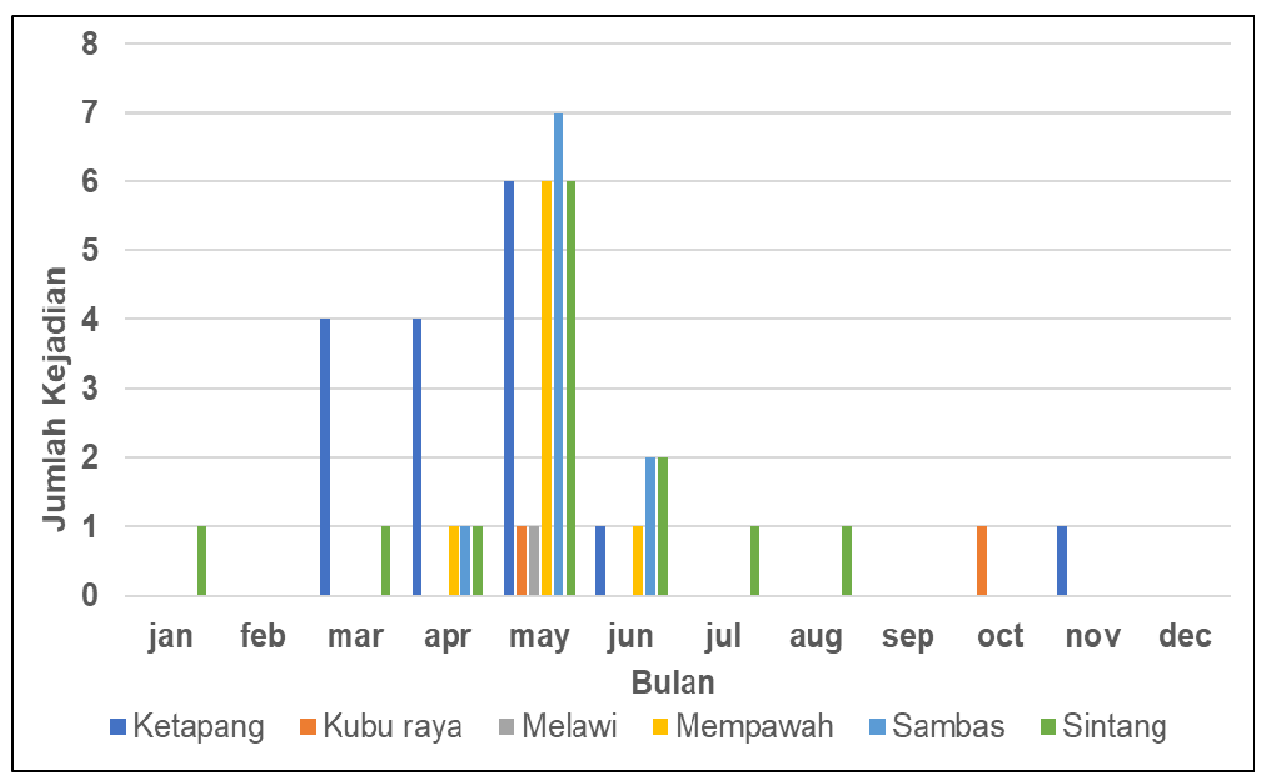

Gambar 5. Interpretasi humidex pada kategori $40-45^{\circ} \mathrm{C}$ masing-masing bulan selama periode 1990-2019. 

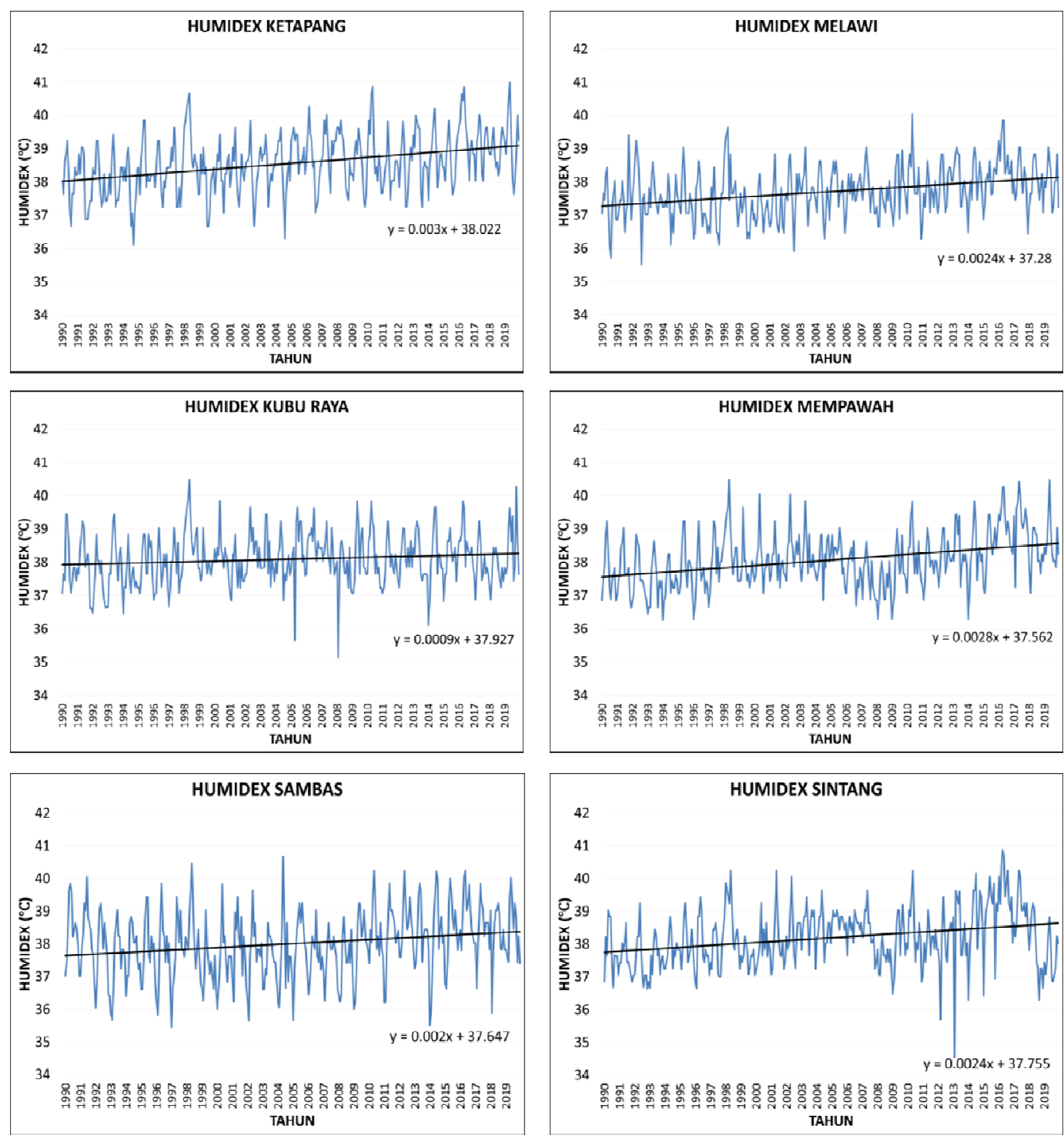

Gambar 6. Tren humidex di lokasi penelitian.

\section{Kesimpulan}

Suhu di Kalimantan Barat mengalami peningkatan selama periode 1990-2019. Peningkatan ini mengindikasikan telah terjadi perubahan iklim di Kalimantan Barat. Humidex juga mengalami tren peningkatan pada periode 1990-2019. Namun, tren peningkatan tersebut masih pada rentang kategori "perasaan tidak nyaman akibat panas" $\left(35^{\circ} \mathrm{C}-39^{\circ} \mathrm{C}\right)$. Hal ini menunjukkan sensasi panas Kalimantan Barat yang dirasakan pada tahun 2019 secara umum masih sama dengan yang dirasakan pada tahun 1990. Namun, frekuensi bulan dengan kategori "Perasaan sangat tidak nyaman akibat panas hingga menimbulkan rasa tersengat akibat panas" $\left(40^{\circ} \mathrm{C}-45^{\circ} \mathrm{C}\right)$ mengalami peningkatan signifikan di Ketapang, Sambas, dan Sintang, di wilayah tersebut kecenderungan sensasi kenyamanan termis yang dirasakan semakin 


\section{Daftar Pustaka}

[1] Saputra, A., Avenzora, R., Darusman, D., \& Hermawan, R. (2016). Orientasi Masyarakat Kota Bogor Terhadap Nilai Kenyamanan Udara. Jurnal Penelitian Sosial Dan Ekonomi Kehutanan, 13(3), 177-187. https://doi.org/10.20886/jsek.2016.13.3.177-187.

[2] Wati, T., Informasi, P., Iklim, P., Pusat, J., Layanan, P., \& Iklim, I. (2018). Analisis Kenyamanan Termis Klimatologis di Wilayah DKI Jakarta dengan Menggunakan Indeks Panas ( Humidex ). 4(1).

[3] ASHRAE, S. (2013). Standard 55-2013. Thermal Environmental Conditions for Human Occupancy, 12.

[4] Badan Standar Nasional. (2004). Tata cara perencanaan lingkungan perumahan di perkotaan SNI 03-1733-2004.

[5] Camuffo, D. (2019). Microclimate for Cultural Heritage: Measurement, Risk Assessment, Conservation, Restoration, and Maintenance of Indoor and Outdoor Monuments. Elsevier.

[6] Kalvelage, K., Passe, U., Rabideau, S., \& Takle, E. S. (2014). Changing climate: The effects on energy demand and human comfort. Energy and Buildings, 76, 373-380.

[7] Siregar, D. C., Lubis, N. A.-Z., \& Muhajir, M. (2020). Analisis Kenyamanan Termis Kota Banda Aceh Berdasarkan Temperature Humidity Index, Discomfort Index dan Humidex. Widyakala: Journal of Pembangunan Jaya University, 7(1), 48. https://doi.org/10.36262/widyakala.v7i1.296

[8] Ropo, O. I., Perez, M. S., Werner, N., \& Enoch, T. I. (2017). Climate variability and heat stress index have increasing potential ill-health and environmental impacts in the East London, South Africa. Int. J. Appl. Eng. Res, 12(17), 6910-6918.

[9] Mehrotra, S., Bardhan, R., \& Ramamritham, K. (2019). Outdoor thermal performance of heterogeneous urban environment: An indicatorbased approach for climate-sensitive planning. Science of the Total Environment, 669, 872-886.

[10] Karyono, T. H. (2004). Penelitian Kenyamanan Termis di Jakarta sebagai Acuan Suhu Nyaman Manusia Indonesia. DIMENSI (Journal of Architecture and Built Environment), 29(1).

[11] Masterton, J. M., \& Fa, R. (1979). a Method of quantifying human Discomfort Due to excessive heat and humidity. cli 1-79: aes, environment canada. Downsview, Ontario.

[12] Scoccimarro, E., Fogli, P. G., \& Gualdi, S. (2017). The role of humidity in determining scenarios of perceived temperature extremes in Europe. Environmental Research Letters, 12(11), 114029.

[13] Rana, R., Kusy, B., Jurdak, R., Wall, J., \& Hu, W. (2013). Feasibility analysis of using humidex as an indoor thermal comfort predictor. Energy and Buildings, 64, 17-25.

[14] Ardi, I. R., Lubis, M. S., \& Fitrianingsih, Y. (2010). Analisis Urban Heat Island Dalam Kaitannya Terhadap Perubahan Penutupan Lahan Di Kota Pontianak. 1-10.

[15] Charalampopoulos, I., Tsiros, I., ChronopoulouSereli, A., \& Matzarakis, A. (2013). Analysis of thermal bioclimate in various urban configurations in Athens, Greece. Urban Ecosystems, 16(2), 217233. https://doi.org/10.1007/s11252-012-0252-5.

[16] Spridonov, V., Curic, M., \& Zafirovski, O. (2013). Weather and Human Health. Macedonian: COBISS MK.

[17] Basyaruddin, Effendy S. 2007. Keterkaitan Cuaca di Indonesia dengan Fenomena Bintik Matahari (Sunspot). Jurnal Agromet Indonesia 21(1):36-46

[18] Alfano, F. R. D. Riccio G., Palella, B. I. 2007. Humidex: can a biometeorological Index profitably lead to the Indoor Thermal Environment Assessment.

[19] Afif, M., Anshari, G. Z., \& Tangdililing, A. B. (2017). Persepsi Petani Terhadap Temperatur dan Hujan di Pontianak. 1-12.

[20] Masitoh, F., \& Rusydi, A. N. (2020). Climatological Human Comfort Using Heat and Humidity Index (Humidex) in Gadingkulon, Malang. IOP Conference Series: Earth and Environmental Science, 412(1). https://doi.org/10.1088/17551315/412/1/012026

[21] Tsutsumi, H., Tanabe, S., Harigaya, J., Iguchi, Y., \& Nakamura, G. (2007). Effect of humidity on human comfort and productivity after step changes from warm and humid environment. Building and Environment, 42, 4034-4042. https://doi.org/10.1016/j.buildenv.2006.06.037.

[22] Amasuomo, T. T., \& Amasuomo, J. O. (2016). Perceived thermal discomfort and stress behaviours affecting students' learning in lecture theatres in the humid tropics. Buildings, 6(2), 18. 